\title{
O tożsamości nauk o bezpieczeństwie
}

\section{The Identity of the Science of Safety}

\section{- Abstrakt •}

W artykule przedstawiono prawne aspekty usytuowania nowej dyscypliny naukowej - nauk o bezpieczeństwie w systematyce nauki polskiej. Zdefiniowano uwarunkowania genezy tej dyscypliny wynikające ze wzrostu zagrożeń dla bezpieczeństwa w wymiarze globalnym. Następnie przeanalizowano zainteresowania problematyką bezpieczeństwa w innych dyscyplinach naukowych i wynikające $z$ tego powodu trudności z jednoznacznym określeniem tożsamości nauk o bezpieczeństwie. Autor zaproponował ujęcie funkcjonalne związku między stanem bezpieczeństwa a zagrożeniem w kontekście analizy ryzyka.

Słowa kluczowe: nauka, dyscyplina naukowa, tożsamość, bezpieczeństwo, zagrożenie

\section{- Abstract •}

The article presents the legal aspects of the positioning of a new scientific discipline - the science of safety in the systematics of Polish science. The determinants of the genesis of this discipline derive from the growing threat to global security. Subsequently, interest in security issues in other scientific disciplines was analyzed, and the resulting difficulty in identifying the identity of the safety sciences was clearly outlined. The author proposed a functional approach to the relationship between safety and risk in the context of risk analysis.

Keywords: science, scientific discipline, identity, safety, threat.

Sześć lat temu na podstawie uchwały Centralnej Komisji do Spraw Stopni i Tytułu Naukowego z 28 stycznia 2011 r. utworzono kilka nowych dyscyplin naukowych, w tym także nauki o bezpieczeństwie, które obok nauk o obronności usytuowano w dziedzinie nauk humanistycznych. W związku ze zmianami prawnymi wynikającymi z kolejnej reformy systemu nauki w naszym kraju minister właściwy ds. nauki i szkolnictwa wyższego uzyskał prawo do zmiany systematyki nauki polskiej. Z tego uprawnienia skorzystał 8 sierpnia 2011 r., wydając roz- 
porządzenie w tym zakresie (Dz.U. 2011, Nr 179, poz. 1065.). W zasadzie utrzymano poprzedni stan rzeczy, z tą zmianą, iż reaktywowano dziedzinę nauk społecznych, w których znalazły się dwie wspomniane dyscypliny. Aktualnie w Polsce mamy 8 obszarów wiedzy, 22 dziedziny, w tym 7 bez podziału na dyscypliny, oraz 95 dyscyplin naukowych.

Nie wchodząc w szczegółową analizę obowiązującej systematyki, należy zwrócić uwagę, że kilka dyscyplin funkcjonuje w ramach kilku dziedzin:

- biotechnologia (3),

- biochemia (2),

- ochrona środowiska (2),

- nauki o zarządzaniu (2),

lub o podobnym charakterze, jak finanse i ekonomia oraz prawo, nauka o administracji i prawo teologiczne. Świadczy to o tendencji do nadmiernego rozdrobnienia, która w pewien sposób jest uzasadniona przez:

- gwałtowny rozwój nauki,

- zapotrzebowanie na wąską specjalizację naukową.

Pozostaje kwestia, jak budować schematy klasyfikacyjne dyscyplin i pól badawczych, aby oddać naturę współczesnej nauki - w coraz większym stopniu składającej się z interdyscyplin, multidyscyplin i transdyscyplin. Jednak ta tendencja paradoksalnie pozostaje w sprzeczności z praktyką legislacyjną ostatnich lat, która zwiększa liczbę dyscyplin naukowych. Polskie realia odbiegają od proponowanej przez OECD - Organizację Współpracy Gospodarczej i Rozwoju klasyfikacji dyscyplin i dziedzin naukowych, w której uwzględniono jedynie 7 dziedzin i 43 dyscyplin. Zarówno w dziedzinie nauk humanistycznych, jak i społecznych nie uwzględniono nauk o bezpieczeństwie i obronności. Przedstawiona klasyfikacja jest radykalnym rozwiązaniem, tym bardziej że w każdej dziedzinie utworzono jedną dyscyplinę naukową o niejasnym charakterze - inne nauki społeczne. Trzeba też pamiętać, iż omawiana klasyfikacja została stworzona w 2004 r., to jest w okresie, gdy urzeczywistniały się dopiero globalne zagrożenia dla bezpieczeństwa globalnego i regionalnego.

Podziały w nauce zmieniają się niczym obrazy w kalejdoskopie. Choć dziedziny i dyscypliny naukowe lubią odwoływać się do swych rzekomo odwiecznych tradycji, w rzeczywistości zmieniają się bardzo szybko. Stanowi to odbicie stale zmieniającej się wokół nas rzeczywistości. $Z$ jednej strony chcielibyśmy zachować pewną stabilność w postrzeganiu obszarów badań naukowych, ale z drugiej ciągle czujemy pokusę przełamywania barier i murów granicznych tradycyjnych dyscyplin nauki. Według Heinza Heckhausena wyróżnia się następujące elementy dyscyplin: 
- przedmiot badań - rozumiany w sposób niespecjalistyczny,

- poziom teoretycznej integracji - z reguły niski we wczesnych fazach rozwoju dyscypliny i wysoki w jej fazach dojrzałych,

- metody - rozwijane dla rozumienia materii dyscypliny oraz dla przekładania danych doświadczalnych na informacje pozwalające na rozwiązywanie problemów badawczych,

- narzędzia analityczne - takie jak statystyka, modelowanie i symulacje, zazwyczaj wspólne dla wielu dyscyplin,

- stopień związku dyscypliny z praktyką - decydujący o jej strukturze i miejscu, jakie zajmuje na wyższych uczelniach,

- uwarunkowania historyczne (Stichweh, 1992).

W Polsce przyjmuje się, że całość wiedzy naukowej pod względem złożoności obszaru badań i problematyki ułożona jest według pewnej hierarchii. Największą jednostką jest obszar badań, który jest dość niedookreśloną platformą aktywności naukowej. W jego skład wchodzą dziedziny naukowe, które stanowią logiczną i treściową zwartą część nauki. Główna aktywność badawcza koncentruje się w ramach dyscypliny naukowej. Ich wyniki kształtują specyfikę tożsamości i celów badawczych. W wielu dyscyplinach tworzone są specjalności badawcze (kierunek badawczy), subdyscypliny lub gałęzie nauki, czyli trwale ukształtowany zespół problematyki w ramach jakiejś dyscypliny naukowej (Szynowski, 2014). Z jednej strony świadczy to o stopniu integracji przedmiotu badawczego, a z drugiej stanowi pewien etap w kształtowaniu się nowej dyscypliny naukowej. Od strony teoretycznej podkreśla się zazwyczaj moment jednolitości, integralności i autonomiczności tego wycinka nauki. Z bardziej praktycznego punktu widzenia dyscyplina naukowa może stanowić jednostkę dydaktyczną (na tyle bogatą i jednolitą część nauki, że nadaje się do nauczania na poziomie szkolnictwa wyższego w charakterze osobnego kierunku studiów) lub organizacyjną (katedrę, zakład naukowy; Szynowski, 2014). Ten aspekt powiązania procesu naukowego z edukacją na poziomie wyższym dość często traktowany był po macoszemu. Zapotrzebowanie na kształcenie na poziomie akademickim w obszarze bezpieczeństwa powinno stanowić praktyczną inspirację do badań empirycznych i podstawowych. Zakładając, że poszczególna nauka to wyraźnie autonomiczna (pod względem badawczym i organizacyjnym) część poznania, będąca dyscypliną naukową bądź zespołem kilku dyscyplin, w ostatnich latach mamy do czynienia z procesem „rozluźnienia” kryteriów „dyscypliny naukowej”. Dawniej wymagano od dyscyplin stosunkowo wysokiego poziomu refleksji metodologicznej, obecnie (choć nie bez oporów) dopuszcza się uprawianie „obszarów wiedzy”, grupowanych pod nagłówkiem „badań” (ang. studies). Dyscyplina naukowa według L. Krzyżanowskiego 
(w znaczeniu instytucjonalnym) to usystematyzowany ze względu na przedmiot i cele procesu poznania oraz społeczne znaczenie jego rezultatów zbiór ukształtowanych i wyodrębnionych części zasobu wiedzy o rzeczywistości. Nauka obejmuje całokształt zakresów wiedzy, jakie wyznaczają granice danej dyscypliny naukowej. Dyscyplina naukowa to doniosła społecznie, ukształtowana i wyodrębniona ze względu na przedmiot i cel badań lub kształcenia część nauki w znaczeniu instytucjonalnym, uznana za podstawową jednostkę jej klasyfikacji (Krzyżanowski, 1994). W przypadku nauki o bezpieczeństwie mamy do czynienia z procesem kształtowania się nowej dyscypliny naukowej, jednak mającej bardzo istotne znaczenie społeczne. W dzisiejszych czasach tempo rozwoju nauki jest ogromne, co wynika ze zmieniającego się świata i potrzeb praktyki. Współczesny świat nie pozostaje pozbawiony odczuwanych i realnych zagrożeń, których genezy należy upatrywać w napięciach politycznych, ekonomicznych, nacjonalizmie, antagonizmach etnicznych czy religijnych. Sprzeczność i zróżnicowanie interesów generuje niebezpieczeństwa o wielorakim charakterze: od konfliktów zbrojnych i zamachów terrorystycznych do przestępczości pospolitej i zorganizowanej, ekscesów chuligańskich, infekowania systemów informatycznych czy korupcji. Obok niebezpieczeństw wywoływanych postawą i działalnością człowieka, niebagatelnego znaczenia dla bezpieczeństwa nabierają też kataklizmy naturalne. Proces globalizacji powoduje, że również zagrożenia o charakterze międzynarodowym szybko stają się realnym niebezpieczeństwem destabilizującym bezpieczeństwo krajowe bądź lokalne. W związku z tym wyspecjalizowane instytucje państwowe powinny być przygotowane, aby zapobiegać tego rodzaju zagrożeniom, a w razie ich zaistnienia - podjąć działania prewencyjne i represyjne. Jedną z podstawowych potrzeb ludzkich jest poczucie bezpieczeństwa osobistego, dlatego też pierwotną funkcją administracji państwowej była funkcja reglamentacyjno-policyjna. Już u zarania instytucji państwa można odnaleźć pierwowzory współczesnej administracji, zajmującej się ochroną porządku i ładu publicznego. Dyskusje na temat państwa i jego roli dotyczyły przede wszystkim tej funkcji, czyli zapewnienia bezpieczeństwa. Już w starożytnej Grecji można odnaleźć początki teoretycznej refleksji o państwie, przede wszystkim w dziełach Platona i Arystotelesa. Wykształciły się wówczas zręby teorii ustroju państwowego. Służby porządkowe przeszły długą drogę ewolucji - od podmiotów o bardzo szerokim zakresie działania do bardzo wyspecjalizowanych. Współczesne państwa dysponują rozbudowaną administracją publiczną, która w dużej części wykonuje zadania z zakresu ochrony porządku i bezpieczeństwa obywateli, ale również chroni obowiązujący porządek prawny i konstytucyjny oraz zabezpiecza przed zagrożeniami zewnętrznymi. 
Reasumując, należy stwierdzić, że poczucie bezpieczeństwa jest immamentną wartością życia każdej jednostki ludzkiej, struktur społecznych, instytucji państwowych oraz występowało w relacjach międzynarodowych. W związku z tym było przedmiotem refleksji naukowej różnych dyscyplin naukowych. W niektórych sytuacjach mieliśmy do czynienia z formowaniem się subdyscyplin lub odrębnych pół badawczych związanych z tematyką odnoszącą się mniej lub bardziej bezpośrednio do bezpieczeństwa.

Problematyka bezpieczeństwa stanowiła obiekt zainteresowań badawczych w innych dyscyplinach naukowych. Należy stwierdzić, iż w krajach Europy Zachodniej i w przypadku nauk historycznych było naturalne, że przedmiotem badań była analiza rozwoju instytucji bezpieczeństwa oraz stan bezpieczeństwa i zagrożenie przestępczością w poszczególnych krajach ${ }^{1}$. W naszych rodzimych warunkach były traktowane po macoszemu jako swoiste uzupełnienie podstawowych dociekań historycznych, w przeciwieństwie do innych krajów, a zwłaszcza Francji, gdzie uzyskały status ważnego obszaru eksploracji badawczych. Przedmiotem szczególnej aktywności francuskich historyków były dzieje policji. Można przyjąć, że we Francji najwcześniej historycy skupili swoje zainteresowania na dziejach rodzimych służb policyjnych, ale też badali narodziny nowoczesnej policji w Europie (Napoli, 2003). Szczególną pozycję w tej dziedzinie mają prof. Paolo Napoli z Ecole des Hautes Etudes en Sciences Sociales (EHESS) oraz prof. Jean-Marc Berliere, który jest też znanym popularyzatorem najnowszej historii policji francuskiej Podobnie traktowane są kwestie bezpieczeństwa w dziedzinie nauk prawnych. $Z$ jednej strony polityka karna jest ściśle związana ze stanem poczucia bezpieczeństwa obywateli i państwa, jednak poza kryminologią i kryminalistyką zagadnienia bezpieczeństwa są przez prawników traktowane jako marginalne. Z kolei w latach 70 . Gary Becker bliżej zajął się tematem ekonomiki przestępczości, która stała się dzięki jego wkładowi wyodrębnioną dziedziną badań. W zakresie tej tematyki Becker podjął, jako główny problem, na podstawie pozytywnej teorii zachowań przestępczych, normatywną kwestię optymalnej polityki wobec przestępczości. Myśl, że „przestępstwo nie popłaca” została tu rozwinięta w teorię ekonomiczną, która została szeroko uznana za poważny wkład Beckera, choć wzbudziła i nadal budzi liczne kontrowersje dotyczące zwłaszcza zasadności zastosowania ekonomicznego podejścia do tej problematyki (Becker, 1974). Jednakże Teoria przestęstwa autorstwa laureata Nagrody Nobla Gary Beckera w 1967 roku była znaczącym dziełem, które przyczyniło się do zaangażowania elementów psychologicznych do podejmowania

${ }^{1}$ Tę problematykę podejmował autor tego artykułu, ale też P. Majer, A. Pepłoński, J. Konieczny, A. Abramski i wielu innych. 
decyzji ekonomicznych; Becker jednakże nalegał na podtrzymywanie ścisłej spójności preferencji. W mniejszym zakresie inne dyscypliny posiłkują się problemami bezpieczeństwa w swoich badaniach empirycznych. Przykładowo, są prowadzone socjologiczne badania ankietowe subiektywnego poczucia bezpieczeństwa obywateli. Z kolei pedagogika jako nauka o wychowaniu, istocie, celach, treściach, metodach, środkach i formach organizacji procesów wychowawczych podejmuje zagadnienia patologii i niedostosowania społecznego wśród młodzieży.

Przedstawione korelacje poszczególnych dyscyplin naukowych z problematyką bezpieczeństwa odnoszą się przede wszystkim do obszaru bezpieczeństwa wewnętrznego (internal security), którego zakres przedmiotowy w poszczególnych krajach jest rozmaity. Ma ono ścisły związek z zagrożeniami, które realnie w tych krajach występują. W Stanach Zjednoczonych, gdzie określane jest jako tzw. domowe bezpieczeństwo (homeland security), obejmuje następujące zagadnienia: ochrona granic, terroryzm międzynarodowy, przestępczość zorganizowana, zwłaszcza narkotykowa, katastrofy naturalne i techniczne oraz szpiegostwo. W strategii Unii Europejskiej z 2010 r. wyróżniono główne i wspólne dla Europy zagrożenia: terroryzm, przestępczość ciężką i zorganizowaną, cyberprzestępczość, przestępczość transgraniczną, zjawisko przemocy oraz klęski żywiołowe i antropogeniczne. W naszych rodzimych warunkach zakres przedmiotowy bezpieczeństwa wewnętrznego został przyjęty bardzo szeroko, a może bardziej właściwe byłoby określenie, że traktowanie tego problemu w teorii i praktyce jest dość swobodne i dowolne. Nie sprzyja to kształtowaniu się tożsamości nauk o bezpieczeństwie, a także nie do końca jest uprawnione mówienie o interdyscyplinarności tej nowej dyscypliny naukowej. Bardziej właściwe jest traktowanie badania różnych aspektów bezpieczeństwa przez pryzmat multidyscyplinarności, czyli udziału komponentów różnych dyscyplin naukowych w procesie badawczym (Żukowska, 2016).

Natomiast w obszarze bezpieczeństwa zewnętrznego mamy do czynienia z samodzielnymi, a przede wszystkim jednorodnymi badaniami naukowymi w ramach tzw. nauk wojskowych oraz studiów międzynarodowych. W tym pierwszym przypadku skupiały się one na zagrożeniach militarnych, które były bardzo aktualne w okresie zimnej wojny. Skutkowały studiami strategicznymi, gdzie dominowały względy militarne. Upadek muru berlińskiego, który był symbolem zakończenia zimnej wojny, oraz atak terrorystyczny w Nowym Jorku 11 września 2001 r. stanowily zakończenie tradycyjnego rozumienia bezpieczeństwa międzynarodowego. Globalizacja współczesnego świata, eskalacja zagrożeń, które mają charakter pozapaństwowy, oraz wzrost roli podmiotów ponadpaństwowych spowodowały jednocześnie rozwój studiów nad bezpieczeństwem. Przełomowe znaczenie miały ustalenia szkoły kopenhaskiej, a zwłaszcza prace Barry’ego Buzana, który stworzył szersze 
ramy bezpieczeństwa, oparte na pięciu sektorach: militarnym, politycznym, ekonomicznym, ekologicznym oraz społecznym (Buzan, 1998).

Status nauk o bezpieczeństwie w jakimś stopniu przypomina pozycję nauki o administracji w ramach nauk prawnych, która według opinii profesora Huberta Izdebskiego przeżywa „kryzys identyfikacji”, czyli problem z własną tożsamością. Pomimo ogromnego zainteresowania studiami administracyjnymi w Polsce widoczna jest tendencja koegzystencji badawczej i edukacyjnej z prawem jako odrębną dyscypliną naukową, z perspektywą wchłonięcia nauki o administracji. Można doszukiwać się pewnych podobieństw z naukami o bezpieczeństwie w zakresie ogromnego popytu na ofertę edukacyjną w tym obszarze oraz prób politologicznego oglądu przedmiotu badań nad bezpieczeństwem. Problemem tej młodej dyscypliny naukowej jest brak wewnętrznej specjalizacji. Taką logiczną próbą jest wyróżnienie dwóch podstawowych subdyscyplin: bezpieczeństwa wewnętrznego i zewnętrznego (nie zawężać do militarnego). Przy braku jednorodności ontologicznej i metodologicznej grozi nam utrata względnej autonomiczności. Należy się zgodzić z poglądem J. Ziarko, że nauki o bezpieczeństwie to budująca się dyscyplina naukowa, która nie ma precyzyjnie zakreślonych granic poznawczych, nie ma też wypracowanych metod badania, w związku z powyższym nadal powinna poszukiwać treści swoich dociekań, jak również odpowiednich procedur badawczych (Ziarko, 2010).

Bezpieczeństwo zarówno w wymiarze krajowym, jak i międzynarodowym stało się obszarem zainteresowań instytucji państwowych oraz organizacji i struktur międzynarodowych. Jest również przedmiotem zintensyfikowanych badań naukowych, konferencji i sympozjów. Najistotniejszym wynikiem tej refleksji jest coraz bogatszy dorobek myślowy w postaci publikacji naukowych. Bezpieczeństwo stało się też istotną ofertą edukacyjną na poziomie wyższym. Aktualnie na około 140 uczelniach kształcą się studenci na kierunkach: bezpieczeństwo wewnętrzne, bezpieczeństwo narodowe i inżynieria bezpieczeństwa. Na tych uczelniach powstają struktury organizacyjne (wydziały, katedry, zakłady), w których instytucjonalnie „polem wiedzy” jest problematyka bezpieczeństwa.

Próby ograniczenia aktywności naukowej do sfery praktycznej - budowania różnych modeli systemów bezpieczeństwa narodowego - nie pozwalają na rozwój tej młodej dyscypliny naukowej (Dawidczyk, Gryz, Koziej, 2006; Wróblewski, 2010). Potrzebuje ona prowadzenia badań podstawowych dla stworzenia zrębów teorii bezpieczeństwa. „Podkreśla się, że uwzględniając kryterium stosowalności wyników badań, naukom o bezpieczeństwie bliżej jest do nauk stosowanych (usługowych) niż czystych (podstawowych). Uważa się, że nauki o bezpieczeństwie traktować należy jako empiryczne (indukcyjne) nauki realne z przewagą badań stosowanych, niemniej w znacznej części badań, szczególnie tych poświęco- 
nych identyfikowaniu podstaw poznawczych zjawisk bezpieczeństwa narodowego, prowadzone będą także badania podstawowe, metodami dedukcyjnymi właściwymi logice i matematyce" (Glen, 2011). Wszystkie użyte argumenty w cytowanej wypowiedzi są w pełni uzasadnione. Jednak bez samodzielnej teoretycznej refleksji trudno będzie uzasadnić potrzebę odrębnej dyscypliny naukowej.

W zakresie tej dyscypliny powinny pozostawać następujące problemy badawcze:

I. Ogólna teoria bezpieczeństwa:

- teoria bezpieczeństwa,

- historia bezpieczeństwa,

- filozofia bezpieczeństwa,

- metodologia badań nad bezpieczeństwem.

II. Rodzaje bezpieczeństwa:

- bezpieczeństwo globalne,

- bezpieczeństwo narodowe,

- bezpieczeństwo publiczne,

- bezpieczeństwo społeczne,

- bezpieczeństwo ekonomiczne,

- bezpieczeństwo wewnętrzne państwa.

III. Instytucje bezpieczeństwa:

- polityka bezpieczeństwa,

- projektowanie i ocena systemów bezpieczeństwa,

- instytucje rządowe na poziomie centralnym i terenowym,

- instytucje samorządu terytorialnego,

- organizacje pozarządowe,

- podmioty prawa prywatnego,

- instytucje Unii Europejskiej,

- organizacje międzynarodowe.

IV. Obszary zagrożeń:

- identyfikacja i ocena zagrożeń w skali globalnej, krajowej i lokalnej;

- identyfikacja i zarządzanie sytuacjami kryzysowymi,

- terroryzm międzynarodowy,

- przestępczość i patologie społeczne,

- kataklizmy naturalne i awarie techniczne.

Kolejnym istotnym problemem jest określenie zakresu przedmiotu badań. Ma to kapitalne znaczenie dla próby zdefiniowania tożsamości dla tej dyscypliny naukowej. Wielu badaczy przywiązuje dużą wagę do systemowego i organizacyjnego ujęcia bezpieczeństwa. Przykładowo, A. Glen uważa, że przedmiotem eksploracji badawczej powinny być współczesne systemy bezpieczeństwa w wymia- 
rze militarnym i pozamilitarnym oraz ich funkcjonowanie na różnych poziomach organizacyjnych. Bardziej pogłębioną propozycję przedkłada P. Sienkiewicz, który stwierdza, że naukę o bezpieczeństwie można traktować jako teorię i inżynierię bezpieczeństwa systemów. Autor wyróżnia dwa podstawowe nurty badań: tworzenie teoretycznych podstaw bezpieczeństwa systemów (technicznych i społecznych) oraz projektowanie systemów bezpieczeństwa, w tym systemów zarządzania bezpieczeństwem oraz zarządzania ryzykiem (ze szczególnym uwzględnieniem sytuacji kryzysowych; Sienkiewicz, Świeboda, 2010). Rozwinięciem tej propozycji badawczej są konstatacje J. Świniarskiego i W. Chojnackiego, którzy rozpatrują problematykę bezpieczeństwa z punktu nauki o cywilizacji i cybernetyczno-technicznej wiedzy o bezpieczeństwie oraz naukach wojskowych; autorzy wiążą bezpieczeństwo z cybernetycznym konstruowaniem takich systemów, które charakteryzuje niezawodność (Świniarski, Chojnacki, 2007). Przedstawione poglądy mają dużą wartość poznawczą. Eksponują z różnych punktów widzenia znaczenie systemowego traktowania bezpieczeństwa.

Należy jednak zwrócić uwagę na zasadniczy problem, jakim jest funkcjonalny związek pojęć bezpieczeństwa jako pewnego stanu podmiotu i zagrożeń dla niego (jego źródeł, charakteru i rodzajów). Należy rozpocząć od poznania natury zjawiska bezpieczeństwa współcześnie rozpatrywanego w następujących kategoriach:

- bezpieczeństwo jednostki (wymiar subiektywny),

- bezpieczeństwo struktur społecznych, w tym państwa (teoria państwa),

- bezpieczeństwo międzynarodowe (regionalne i globalne),

aby poddać empirycznej analizie społeczną, cywilizacyjną, technologiczną oraz przyrodniczą rzeczywistość jako źródeł zagrożeń. Mają one wymiar subiektywny (przedmiot badań behawioralnych) i obiektywnych (przedmiot badań nauk ścisłych) Tych dwu zjawisk nie należy traktować dychotomicznie, tylko jako całość. Pozwoli to na badanie procesowe przedmiotu bezpieczeństwa. Upraszczając, można to przedstawić w postaci następującej relacji:

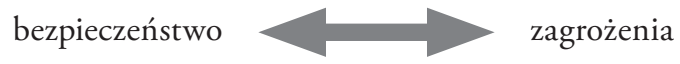

Chciałbym się w tym miejscu odwołać do prezentowanego z całkowicie innego stanowiska badawczego poglądu prof. Jerzego Koniecznego z Uniwersytetu Opolskiego, który w jednej z opinii habilitacyjnych przedstawił interesujące podejście do przedstawionego problemu. W analizie relacji między zagrożeniem a bezpieczeństwem J. Konieczny opisuje dwie wartości, które charakteryzują pierwszy element wspomnianej relacji - prawdopodobieństwo (Beck, 2002) wystąpienia i krytyczność, czyli skutki wystąpienia zagrożenia. Uzupełnieniem tej analizy jest też 
charakterystyka bezpieczeństwa (systemu) z punktu widzenia poziomu odporności. Wszystkie te parametry są stopniowalne i pozwalają określić poziom ryzyka akceptowalnego. Dlatego definiowanie stanu bezpieczeństwa jako stanu bez zagrożeń w świecie rzeczywistym jest stanem nierealnym. Problematyka analizy była przedmiotem przełomowej w socjologii pracy Ulricha Becka Społeczeństwo ryzyka.

Należy stwierdzić, że od prawie dwóch dekad mamy do czynienia z fenomenem zainteresowania problematyką bezpieczeństwa na poziomie praktycznym jako efektem globalnego zagrożenia terroryzmem, boomu edukacyjnego oraz ogromnego rozwoju badań naukowych. Dlatego też odchodzi do lamusa tak charakterystyczne dla epoki zimnej wojny postrzeganie problematyki bezpieczeństwa w kategoriach militarnych. Coraz bardziej uzasadniona staje się analiza systemów bezpieczeństwa poprzez pryzmat uwarunkowań politycznych, społecznych, religijnych i ekonomicznych.

Przedmiotem poznania nauki o bezpieczeństwie powinna być działalność państwa, instytucji międzynarodowych oraz ogół zjawisk i stosunków związanych z zapewnieniem bezpieczeństwa w skali krajowej i globalnej. Można dodać, że zajmować się też powinna analizą zjawisk i procesów społecznych mających wpływ na poziom bezpieczeństwa i ich uwarunkowaniami i konsekwencjami. Obszar zainteresowania nauki o bezpieczeństwie jest bardzo szeroki, zróżnicowany i wielowarstwowy.

Jako że naukę o bezpieczeństwie uważa się za dyscyplinę badającą zjawiska społeczno-polityczne ujmowane jako „kategoria zjawisk społecznych”, posiadającą cechy własne, jak język pojęć oraz przedmiot badań, można wskazać na jej następujące funkcje:

1) deskryptywną, czyli zajmującą się opisem i systematyzacją; poszukuje się tu odpowiedzi na pytanie ,jaka jest rzeczywistość pod względem bezpieczeństwa?";

2) eksplanacyjną, która polega na poszukiwaniu związków przyczynowo-skutkowych między zjawiskami, a także pozwala konstruować teorie; tutaj pytanie brzmi: „dlaczego dane zjawiska zaistniały(występują) lub mają stwierdzone właściwości (cechy własne)?”;

3) prognostyczną, która umożliwia przewidywanie i kształtowanie przyszłości; pyta o to, „jaka będzie rzeczywistość w przyszłości?”;

4) instrumentalną, zajmującą się poszukiwaniem skutecznych sposobów działania - ,jakie podejmować decyzje, aby osiągnąć dane rezultaty lub pożądany stan rzeczy?";

5) ideologiczną, która zajmuje się poszukiwaniem odpowiedzi na pytanie o cele działania. 


\section{Bibliografia:}

Beck, U. (2002). Społeczeństwo ryzyka. W drodze do innej nowoczesności. Warszawa: Wydawnictwo Naukowe Scholar.

Becker, G.S. (1974). Crime and Punishment: An Economic Approach. Journal of Political Economy, Vol. 76, No 2.

Buzan, B. (1998). Security: A New Framework for Analysis. Boulder: Lynne Rienner.

Dawidczyk, A., Gryz, J., Koziej, S. (2006). Strategiczne zarządzanie bezpieczeństwem. Teoria - praktyka -dydaktyka. Łódź: WSH-E.

Glen, A. (2011). Podstawy poznawcze badań bezpieczeństwa narodowego. Zeszyty Naukowe AON, nr 2 (83).

Krzyżanowski, L.J. (1994). O podstawach kierowania organizacjami. Warszawa: PWN.

Napoli, P. (2003). Naissance de la police moderne: pouvoir, norme, societe. Paris: La Decouverte.

Rozporządzenie Ministra Nauki i Szkolnictwa Wyższego z dnia 8 sierpnia 2011 r. w sprawie obszarów wiedzy, dziedzin nauki i sztuki oraz dyscyplin naukowych i artystycznych, Dz.U. 2011, Nr 179, poz. 1065.

Sienkiewicz, P., Świeboda, H. (2010). Perspektywy badań systemowych nad bezpieczeństwem. W: M. Kwieciński (red.), Bezpieczeństwo. Wymiar wspótczesny i perspektywy badań. Kraków: Krakowskie Towarzystwo Edukacyjne - Oficyna Wydawnicza AFM.

Stichweh, R. (1992). The Sociology of Scientific Disciplines: On the Genesis \& Selectivity of the Disciplinary Structure of Moderne Science. Science in Context, vol. 5, $\mathrm{nr} 1$.

Szynowski, R. (2014). Nauki o bezpieczeństwie a nauki o administracji. Studia Iuridica Lublinensia, $\operatorname{nr} 21$.

Świniarski, J., Chojnacki, W. (2007). Bezpieczeństwo jako przedmiot badań wybranych dyscyplin naukowych. W: K. Jałoszyński, B. Wiśniewski, T. Wojtuszek (red.), Wspótczesne postrzeganie bezpieczeństwa. Bielsko-Biała: Wyższa Szkoła Administracji.

Wróblewski, R. (2010). Przedmiot i metoda nauki o bezpieczeństwie narodowym. W: P. Sienkiewicz, M. Marszałek, H. Świeboda (red.), Metodologia badań bezpieczeństwa narodowego, t. I. Warszawa: Wydawnictwo Akademii Obrony Narodowej.

Ziarko, J. (2010). Dylematy metodologiczne bezpieczeństwa jako nauki. W: M. Kwieciński (red.). Bezpieczeństwo. Wymiar wspótczesny i perspektywy badań. Kraków: Krakowskie Towarzystwo Edukacyjne - Oficyna Wydawnicza AFM.

Żukowska, I. (2016). Interdyscyplinarność w polityce badawczej Unii Europejskiej. W: J. Czaputowicz (red.), Studia Europejskie. Wyzwania interdyscyplinarności. Warszawa: Wydział Dziennikarstwa i Nauk Politycznych Uniwersytet Warszawski. 